ISSN 2392-4896 (online)

ISSN 2392-4888 (print)

Journal of Management and Development Studies Vol. 27:pp.49-58

Available online http://nasc.org.np

(C2016Nepal Administrative Staff College

\title{
Present State of Coffee Production and Consumers Behaviour on Preferences of Nepalese Coffee
}

\author{
Yogendra Kumar Karki \\ Joint Secretary, Ministry of Agricultural Development, Nepal \\ Email: ykkarkee@hotmail.com \\ Punya Prasad Regmi \\ Professor, Institute of Agriculture and Animal Science, Tribhuvan University, Nepal \\ punyaregmi@gmail.com
}

Accepted 12 July 2016

Nepal has enormous potential for cultivation of coffee as the climate is suitable throughout the mid hills of the country. High demand of coffee and higher price, comparative to other crops in the internationl market lure farmers for its cultivation. This paper deals with the present state of same product focusing on the production and consumer behaviour on preferences of Nepalese coffee. For the study,growth rate in area, production and yield of coffee was estimated using the secondary information. Similarly import and export trend of coffee was estimated through secondary information. Consumers behaviour on preferences of coffee was analyzed through individual survey by selecting 120 consumers randomly including coffee-drinker and restaurant owners. Semi-structured questionnaire was administred to study the consumers behaviours. The study revelaed that annual growth rate of area under coffee and its production during 1999 to 2013 was 11.61 percent and 10.59 percent, respectively. Whereas, the productivity of coffee during the same period decreased by 1.01 percent. The decline in productivity might be due to problem of irrigation, inadequate nutrient supply and diseases and pests. Large proportion of coffee produced in Nepal is exported. However, the analysis showed that there is decrease of coffee export by 25.6 per cent annually due to increase in local consumption of coffee. Analysis also showed that the foreign people prefer foreign coffee in comparison to Nepalese coffee ( $p$-value is $<0.000)$ and generally consume three cups of coffee per day (p-value $=0.008$ ), while in case of Nepalese consumers, it is only two cups per day.

Keywords: Consumer behaviour, consumer satisfaction, trade 


\section{Present State of Coffee Production and Consumers' Preference on Nepalese Coffee}

\section{Introduction}

Coffee is one of the important beverage crops and consumed by many people daily. It also has high export value in international market. Coffe is fairly a new crop in Nepalse context. Area and production of coffee in Nepal is increasing and now the cultivation has reached upto 42 districts in mid hills of Nepal (MoAD, 2015). Coffee cultivation in Nepal started from Gulmi district and now many farmers are engaged in this enterprize. Majority of the coffee pocket area were predefined as organic coffee to fetch high price through marketing of organic coffee. With the existence of favorable climatic condition together with characteristics of coffee plants that grow well on rain fed uplands, the smallholder farmers are being positively attracted toward coffee farming in Nepal. Coffee provides five times more income than that of maize and millets and 2-3 times more yield than that of any other cash crops (Kattel, 2009). The ecological settings in the Himalayan hills provide Nepalese coffee a unique opportunity to enter international specialty markets. Nepali coffee has been exported as organic coffee produced by resource poor smallholders under organic conditions (PACT, 2012).

According to Ministry of Agriculture Development [MoAD] (2015), coffee production in Nepal in 2014 was $429.4 \mathrm{mt}$ from 1,911 ha of land and productivity was $224.7 \mathrm{~kg} / \mathrm{ha}$. In Nepal, consumers are gradually changing their preferences from tea to coffee. So there is a need to raise consumers' awareness towards coffee. Thus, this study was carried out to identify consumer's behaviors and problems associated with coffee consumption, focusing on consumers response and their level of satisfaction on Nepalese coffee.

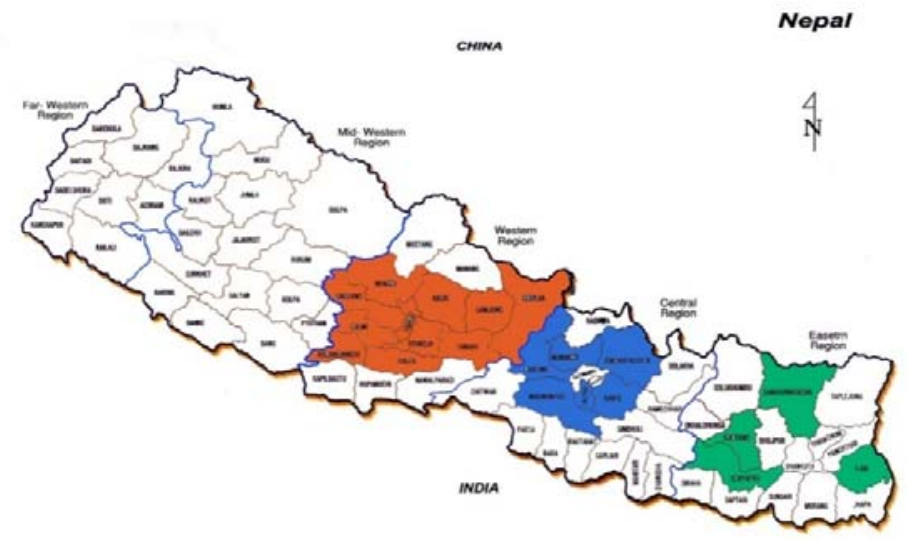

Figure 1: Major coffee producing districts in Nepal (shaded districts) 


\section{Objectives}

Main objective of this study is to assess consumers' preferences towards coffee. The specific objectives are: to find out level of satisfaction among coffee consumers; and to analyze annual growth rate of coffee in area and production along with its, import and export in Nepal.

\section{Methodology}

This study used time series data related to area, production and productivity of coffee from 1999/00 to 2013/14. Similary, import export data were also used to provide status of import and export of coffee in Nepal.

Annual compound growth rate (ACGR) was calculated by the formula:

$\mathrm{Y}_{\mathrm{t}}=\mathrm{AB}^{\mathrm{t}}$

where,

$$
\begin{aligned}
& Y_{\mathrm{t}}=\text { Year } \\
& \mathrm{A}=\text { Intercept } \\
& \mathrm{B}=\text { Area/Production/Export/Import } \\
& \mathrm{t}=\text { Time }
\end{aligned}
$$

This study was carried out with 120 coffee consumers including restaurant owners. All the samples were taken randomly from Lalitpur and Kathmadu districts of Nepal. Semistructured questionnaire was used for collecting information. Consumers preferances were examined based on category of consumers and type of coffee and also frequency of coffee consumption per day. Satisfaction index was calculated based on five point scale $(+1,+0.5,0,-0.5$ and -1$)$.

\section{Characteristics of the respondents}

Out of total 120 respondents, majority of them (90\%) were male. By gender, about 95 percent were male in case of restaurant owners. Similarly, out of the total individual consumers surveyed, 85 percent were male (Table 1). 
Present State of Coffee Production and Consumers' Preference on Nepalese Coffee

Table 1: Distribution of respondents by gender

\begin{tabular}{lcccccc}
\hline \multirow{2}{*}{ Gender } & \multirow{2}{*}{ Individual Consumers } & \multicolumn{2}{c}{ Restaurants } & \multicolumn{2}{c}{ Total } \\
\hline Female & $\mathrm{N}$ & $\%$ & $\mathrm{~N}$ & $\%$ & $\mathrm{~N}$ & $\%$ \\
Male & 9 & 15 & 3 & 5 & 12 & 10 \\
\hline Total & 51 & 85 & 57 & 95 & 108 & 90 \\
\hline
\end{tabular}

Out of the surveyed respondents, majority (82\%) consumers were business person. Among individual respondents, 63 percent were business person and 32 per cent students (Table 2).

Table 2: Occupational status of respondents

\begin{tabular}{lcccccc}
\hline \multirow{2}{*}{ Occupation } & \multicolumn{1}{c}{ Individual Consumers } & \multicolumn{2}{c}{ Restaurants } & \multicolumn{2}{c}{ Total } \\
\cline { 2 - 7 } & $\mathrm{N}$ & $\%$ & $\mathrm{~N}$ & $\%$ & $\mathrm{~N}$ & $\%$ \\
\hline Business & 38 & 63 & 60 & 100 & 98 & 81.67 \\
Farmer & 3 & 5 & 0 & 0 & 3 & 2.50 \\
Student & 19 & 32 & 0 & 0 & 19 & 15.83 \\
\hline Total & 60 & 100 & 60 & 100 & 120 & 100 \\
\hline
\end{tabular}

More than half of the respondents were found to have higher secondary and above level of education, less than 10 percent had lower secondary and, remaining 18 percent had secondary level of education (Table 3 ). 
Present State of Coffee Production and Consumers' Preference on Nepalese Coffee

Table 3: Education level of respondents

\begin{tabular}{lcccccc}
\hline \multirow{2}{*}{$\begin{array}{l}\text { Education } \\
\text { Level }\end{array}$} & \multicolumn{2}{c}{ Individual } & \multicolumn{2}{c}{ Restaurants } & \multicolumn{2}{c}{ Total } \\
\cline { 2 - 7 } & $\mathrm{N}$ & $\%$ & $\mathrm{~N}$ & $\%$ & $\mathrm{~N}$ & $\%$ \\
\hline Lower Secondary & 7 & 11.67 & 3 & 5.00 & 10 & 8.33 \\
Secondary & 6 & 10.00 & 16 & 26.67 & 22 & 18.33 \\
$\begin{array}{l}\text { Higher Secondary } \\
\text { Graduate and }\end{array}$ & 32 & 53.33 & 27 & 45.00 & 59 & 49.17 \\
above & 15 & 25.00 & 14 & 23.33 & 29 & 24.17 \\
\hline Total & 60 & 100 & 60 & 100 & 120 & 100 \\
\hline
\end{tabular}

\section{Area and production of coffee}

The study shows that there is increasing trend in area and production of coffee in between the time period from 1999 to 2013. The production was in increasing trend and reached a maximum level in the year 2006/07 (616 mt) though fluctuation was marked in the later years. Similarly, the area under cultivation was in increasing trend. This might be due to attraction of farmers towards its cultivation as a result of growing demand of coffee in national and international market.

During last five years, it was seen that area under coffee cultivation increased by 32 percent, production increased by more than 55 percent and productivity expanded by 18 percent. Area for cultivation of coffee reached to 1911 hactare, and production was 429 ton in 2013/14. The productivity of coffee was found highest ( $450 \mathrm{~kg} / \mathrm{ha}$ ) during 2005 to 2007. In between 1999/00 to 2013/14, compounded annual growth rate (CAGR) of area under coffee cultivation was calculated to be 12 percent, and production 11 percent. However, the productivity during the same period decreased by aroud one percent annualy. Though the data showed decrease in productivity in average, it had increased by 2.78 per cent during the last five years (Table 4). 
Present State of Coffee Production and Consumers' Preference on Nepalese Coffee

Table 4: Area, production and productivity of coffee in Nepal (1999/00 to 2013/14)

\begin{tabular}{|c|c|c|c|}
\hline Year & Area (ha) & Production (Mt.) & Productivity $(\mathrm{Kg} / \mathrm{ha})$ \\
\hline $1999 / 00$ & 314 & 72 & 229.30 \\
\hline $2000 / 01$ & 424 & 89 & 209.91 \\
\hline $2001 / 02$ & 596 & 139 & 233.22 \\
\hline $2002 / 03$ & 764 & 188 & 246.07 \\
\hline $2003 / 04$ & 925.2 & 217 & 234.54 \\
\hline $2004 / 05$ & 1078 & 307 & 284.79 \\
\hline $2005 / 06$ & 1285 & 579 & 450.58 \\
\hline $2006 / 07$ & 1395.5 & 616 & 441.42 \\
\hline $2007 / 08$ & 1450 & 276 & 190.34 \\
\hline $2008 / 09$ & 1531 & 267 & 174.40 \\
\hline $2009 / 10$ & 1650 & 308 & 186.67 \\
\hline $2010 / 11$ & 1752 & 402 & 229.45 \\
\hline $2011 / 12$ & 1780 & 425 & 238.76 \\
\hline $2012 / 13$ & 1750 & 366 & 209.14 \\
\hline $2013 / 14$ & 1911 & 429.4 & 224.70 \\
\hline Compounded annual growth rate & $11.61 \%$ & $10.59 \%$ & $-1.01 \%$ \\
\hline
\end{tabular}

Source: MoAD, Nepal, 2015

\section{Export and import}

Current trend of area expansion in farmers' level shows that coffee could be one of the high value agricultural crops as a niche product for export. However, the data proved that the export trend has been decreasing. It declined in subsequent years- e.g. in 2014/15 only $100 \mathrm{mt}$ of coffee was exported. Nevertheless, there is huge potential for raising the export in international market. Japan, Korea, Germany, Australia, Taiwan, and U.K. are major countries for exporting Nepali coffee (TEPC, 2015). 
Present State of Coffee Production and Consumers' Preference on Nepalese Coffee

Table 5: Import and export of coffee for last five-year

\begin{tabular}{lcr}
\hline Year & Export $(\mathrm{Kg})$ & Import $(\mathrm{Kg})$ \\
\hline $2010 / 11$ & 279,761 & 31,324 \\
$2011 / 12$ & 109,441 & 28,907 \\
$2012 / 13$ & 85,671 & 51,826 \\
$2013 / 14$ & 66,460 & 62,872 \\
$2014 / 15$ & 99,846 & 111,040 \\
\hline
\end{tabular}

Source: TEPC, 2015

It is revealed that annual growth rate of coffee export was negative by 25.6 percent annually during 2010/11-2014/15. Conversely, the amount of growth in import of this cash crop was 33 percent per annum for the same period. Analysis shows that, in spite of low production, consumption rate of Nepalese coffee during last five year is 5.7 percent. The result suggests that both the demand of coffee in Nepalese market has increased followed by the increase in coffee consumers.

\section{Purchase and consumption}

Small shops are major sources for selling coffee to the restaurant owner while some of the restaurant owners prefer supermarkets and cooperatives. This situation has arisen mainly due to lesser numbers of supermarkets in Kathmandu and vicinity. Majority of the coffee is sold through small retail shops ( 83 percent) (Table 6).

Table 6: Percentage distribution of restaurants purchasing coffee powder by market sources

\begin{tabular}{lcc}
\hline \multirow{2}{*}{ Source } & \multicolumn{2}{c}{ Restaurants } \\
\cline { 2 - 3 } & Number & Percent \\
\hline Small/Retail shop & 53 & 88.33 \\
Cooperatives & 3 & 5.00 \\
Supermarket & 4 & 6.67 \\
\hline Total & $\mathbf{6 0}$ & $\mathbf{1 0 0}$ \\
\hline
\end{tabular}

Coffee consumption pattern was measured by number of cups consumed per day. Result showed that majority $(48.33 \%)$ of the individuals found to have consumed two cups of coffee per day at home. In case of restaurant goers, 43 percent of consumers preferred one cup of coffee and only few consumers were found preferring three or more cup of coffee per day (Table 7). 
Present State of Coffee Production and Consumers' Preference on Nepalese Coffee

Table 7: Percentage distribution of consumer, by drinking location and coffee drink (cups/day) $(\mathrm{N}=60)$

\begin{tabular}{lrrrrrr}
\hline \multirow{2}{*}{ Location } & \multicolumn{7}{c}{ Coffee drink (cups/day) } & \multirow{2}{*}{ Total (N=60) } \\
\cline { 2 - 7 } & 1 & 2 & 3 & 4 & 5 & 100 \\
\hline Home & 40 & 48.33 & 5 & 5 & 1.67 & 100 \\
\cline { 2 - 7 } Restaurant & 43.33 & 35 & 21.67 & 0 & 0 & 100 \\
\cline { 2 - 7 } Others & 54.35 & 28.26 & 10.87 & 6.52 & 0 & 0 \\
\hline
\end{tabular}

Taste and preferences

Analysis on taste and preference of coffee and consumer showed that there is significantly more consumption of imported coffee by foreign people. This conclusion was made from 94 consumers (72 foreign and 22 Nepalese) (Table 8).

Table 8: Taste preference of coffee, by type of consumers

\begin{tabular}{lccc}
\hline Consumer type & Nepalese coffee & Foreign coffee & Total \\
\hline Nepalese & 18 & 4 & 22 \\
Foreign & 18 & 54 & 72 \\
\hline Total & 36 & 58 & 94 \\
\hline
\end{tabular}

Chi-square value $23.0212 * * *$ ( $\mathrm{p}$-value is $<0.000$ )

Majority consumers (58.67\%) were found to prefer foreign coffee. They generally prefer three cup of coffee per day which is significantly different with other. Likewise, four in ten consumers were found to prefer Nepalese coffee (Table 9).

Table 9: Type of coffee consumed per day by consumers

\begin{tabular}{|c|c|c|c|c|c|c|c|}
\hline \multirow{2}{*}{ Type of coffee } & \multicolumn{5}{|c|}{ Coffee consumption (cup/day) } & \multirow{2}{*}{ Total } & \multirow{2}{*}{$\%$} \\
\hline & 1 & 2 & 3 & 4 & 5 & & \\
\hline Nepalese & 6 & 13 & 9 & 3 & 0 & 31 & 41.33 \\
\hline Foreign & 6 & 6 & 16 & 6 & 10 & 44 & 58.67 \\
\hline Total & 12 & 19 & 25 & 9 & 10 & 75 & 100 \\
\hline
\end{tabular}

Chi-square statistics is $13.6971^{* * *}(\mathrm{p}$-value $=0.008)$

\section{Consumers' satisfaction}

Consumer satisfaction was measured in five point scale of satisfaction index. Mix type of result was observed on the satisfaction level of consumers on consumption of 


\section{Present State of Coffee Production and Consumers' Preference on Nepalese Coffee}

Nepalese coffee. Forty percent of the consumers were found satisfied with Nepalese coffee while 17 percent were highly satisfied. Whereas, 22 percent of consumers were dissatisfied with Nepalese coffee consumption (Table 10). From the result, it is found that satisfaction index of the consumers is 0.21 .

Table 10: Satisfaction level of consumer towards Nepalese coffee consumption

\begin{tabular}{lcc}
\hline Satisfaction level & $\mathrm{N}$ & $\%$ \\
\hline Highly satisfied & 10 & 16.67 \\
Satisfied & 24 & 40.00 \\
Indifferent & 10 & 16.67 \\
Dissatisfied & 13 & 21.67 \\
Highly dissatisfied & 3 & 5.00 \\
\hline Total & 60 & 100.00 \\
\hline
\end{tabular}

\section{Conclusion}

Coffee in Nepal is a high value cash crop and has good potential to export. Coffee could significantly contribute to increase income and livelihoods improvement of smallholder farmers in Nepal. The trend of area and production of coffee in Nepal is increasing - 11 percent annually for area and 11 percent for production in last 14 years. However, the productivity has decreased by about one percent. Increase in volume of coffee import and decrease in export in last five years indicate that coffee consumers are increasing day by day. Consumers are changing their preference towards Nepalese coffee. Nearly 40 percent of consumers found to be satisfied with Nepalese coffee. However, most of the consumers of Nepalese coffee are Nepalese themselves. It is also straight worthy that Nepalese coffee market is found dominated by imported coffee due to low price. Retail shops are major sources to buy consumable coffee by majority of consumers. Nepalese coffee is found to be comparatively expensive compared to foreign and less popular in Nepalese market. Therefore, it is not easily available in local market, and consumers are forced to buy imported coffee. Nepalese consumers are found habitual to drink on average, two cups of coffee at home and one cup at restaurant per day. 
Present State of Coffee Production and Consumers' Preference on Nepalese Coffee

\section{References}

Agri-business Promotion \& Statistic Division. (2010). Statistical information on Nepalese agriculture 2009/10. Kathmandu: APSD, MOAC.

Kaplinsky, R. \& Morris, M. (2001). A handbook for value chain research [Report prepared for International Development Research Center]. Place of Publication: Publishing House

Kattel, R.R. (2009). The impact of coffee production on Nepali smallholders in the value chain (Unpublished MSc. Thesis). Leibniz University, Hannover, Germany.

MoAD.(2015). Statistical year book, 2013. Ministry of Agricultural Development,Singhdarbar, Kathmandu.

PACT. (2012). Value chain development plan for organic coffee. Project for Agriculture Commercialization and Trade, Kathmandu

TEPC. (2015). Nepal trade directory 2015. Trade and Export Promotion Center, Lalitpur, Kathmandu. 